\title{
A Review and Analysis of Library Availability Studies
}

\section{By Thomas E. Nisonger}

The concept of availability (can a library patron locate a desired item on a library's shelves?) and Kantor's branching method for identifying barriers to availability (acquisition, circulation, library operations, and the user) are described. A literature review identifies more than fifty investigations of availability reported in journal articles, dissertations, theses, or conference presentations during the last quarter century. The mean availability rates for known-item searches by actual patrons of 61.3 percent or 63.1 percent (depending on the calculation method) are quite similar to the 61 percent found in an earlier review covering the years 1934 to 1984. Analysis of availability in Kantor's branches shows variation among libraries, but no branch standing out as a major barrier. The paper concludes with the argument that the traditional availability measure can be modified for use as an objective, user-centered evaluative tool in the electronic environment.

T ibraries and the library and information science (LIS) discipline are in the midst of a rapid paradigm shift, calling for new research approaches and evaluative measures. During the twentieth century a host of library evaluation techniques that generally focused on the collection itself, including the checklist approach, circulation studies, and the Conspectus, were developed for a relatively stable, mostly print environment. See Lockett for a synopsis of the major approaches. ${ }^{1}$ The Association of Research Libraries (ARL) New Measures Initiative and LibQual, among several possible examples, illustrate how the discipline is now searching for new, user-centered evaluation strategies suitable for a more complex, hybrid print-electronic environment, which may soon morph into an all-electronic environment. This paper concludes with the suggestion that a proven library evaluation technique that has been used for more than seven decades, usually termed an "availability study," can be modified to help meet the evaluation challenges in the emerging environment.

The word "availability" can have a wide variety of meanings, including a politician's availability as a candidate for office or someone's availability for a Saturday night date. Within LIS, the term has been applied to a variety of contexts, including the holding of a journal title by a library or the ability to obtain a book in the out-of-print market, among numerous credible examples. ${ }^{2}$ Yet, availability has a well-established and fairly specific meaning as a library performance or collection evaluation measure. It has been defined as "the extent to which patron needs for specific documents are promptly satisfied" and "immediate access to known-items sought." In essence, availability tests whether a library patron can immediately find whatever document he or she is seeking in the library. The terms "shelf availability study," "failure study," or "frustration study"

.edu) is Professor, School of Library and Information Science, Indiana University.

The author gratefully acknowledges the efforts of his graduate assistants at Indiana University's School of Library and Information Science, Rebecca Kennedy, Sara Franks, and Catherine Hall, who at various times provided clerical support for the writing of this paper. He also thanks the staff of Indiana University's School of Library and Information Science Library for their excellent service. have alternatively been used for this method or variations upon it. 
Availability is often considered a measure of library effectiveness or overall performance. As White stated, "The user doesn't care that the library owns a million books if he can't find the one he wants."4 Availability studies have been compared to systems analysis because they view the library as a system for providing documents demanded by patrons and can identify which subsystem, such as acquisitions or circulation, is responsible for failure. ${ }^{5}$ Investigation of availability constitutes an established LIS research approach that has been used in doctoral dissertations, master's theses, and many refereed journal articles.

The majority of availability studies have been "real," as they were based on surveying actual library patrons during designated time periods, usually asking them to complete a questionnaire reporting the items sought and whether they were found. Some studies have been simulated with library staff checking the shelf availability for a list of citations. A few studies have used log records of patron OPAC searches. ${ }^{6}$ A number of investigations have taken a macro approach, simply calculating an overall availability rate. Many have been conducted at a micro level, using Kantor's branching technique (as will be explained further in this paper) to analyze why books and articles were not available. This macromicro distinction is based on Lancaster's work. ${ }^{7}$

A number of sources have reviewed the advantages and disadvantages of availability studies, including Lockett, and Bachmann-Derthick and Spurlock. ${ }^{8}$ The advantages of the approach include: provision of objective data concerning the library's ability to meet patron need, use of a well-established methodology, and repeatability at later or even regular intervals allowing longitudinal comparison. Also, bottlenecks can be identified and policy changes or appropriate corrective actions can be made.

The disadvantages associated with availability tests are their design and implementation can be relatively complex and time-consuming; user cooperation is required; users may not accurately report the necessary information; the needs of nonusers are not addressed; and, because they are based on a sample, they only provide an estimate of overall availability.

This paper's purpose is to review and tabulate the results of more than thirty-five studies reporting more than fifty availability tests conducted or published since the early 1980s, focusing on overall availability rates and the reasons items were not available to patrons. The potential applicability of the availability concept to the electronic environment is then advocated.

\section{A Brief Historical Sketch of Availability Studies}

Studies of availability have appeared in the literature for at least seven decades. Gaskill, Dunbar, and Brown's 1934 use survey at the Iowa State College library calculated the percentage of time both undergraduate students and graduate students "obtained what they sought" and identified eleven reasons for failure to locate the sought-after book or magazine. ${ }^{9}$ In 1975, Buckland's major monograph, Book Availability and the Library User, based on research at the University of Lancaster, reported that circulation was the major barrier to book availability, and recommended variable loan periods and purchase of duplicate copies to increase availability. ${ }^{10}$

At least forty availability studies were published between the 1930s and the mid-1980s, according to a seminal literature review and analysis published in 1986 by Mansbridge. ${ }^{11}$ He discovered that most investigations were based on known-item searches conducted in academic libraries, while two-thirds were based on real users, and the remaining third used a set of citations simulating user needs. This literature review will only mention the most seminal items included in Mansbridge, while focusing on research published later or not covered by him.

\section{Kantor's Branching Method}

"The branching method," developed by Kantor during the 1970s, is probably the best-known availability technique and the one most frequently employed in research. Kantor's original 1976 article, which reported results at Case Western University's Freiberger Library, outlined four branches or barriers to patron "satisfaction" in obtaining a desired book, which are generally termed: "acquisitions"-it was not acquired; "circulation"-it is checked out to another patron; "library operations" - it is not in the correct shelf location; and "the user"-it can not be located when correctly shelved. ${ }^{12}$ Later modifications added a "bibliographic" branch - the user did not have the correct citation-and a "catalog" branch - the user could not locate the book in the catalog and record the correct call number. ${ }^{13}$ Rashid used a "collection development policy" branch (actually a subdivision of the acquisitions branch), whereby the desired title was not covered by the collection development policy's scope.$^{14}$ Two additional branches have been used in the small number of studies of subject searching-i.e., the patron is seeking a book on a particular subject rather than a specific title- "appropriate title," in which the patron deems a book listed in the catalog inappropriate due to such factors as age, language, or reading level; and "matched query," in which the client fails to find a subject heading in the catalog matching his or her information need. ${ }^{15}$

Numerous permutations of branches have been used in the studies based on Kantor's methodology. The three most frequently used sets of branches for known-item searches by patrons are 
- Acquisitions, Circulation, Library Operations, User;

- Acquisitions, Catalog, Circulation, Library Operations, User; and

- Bibliographic, Acquisitions, Catalog, Circulation, Library Operations, User. ${ }^{16}$

Other less frequently employed permutations include "Acquisitions, Catalog, Circulation, and Library"-because the investigation took place in a closed stack library; "Bibliographic, Collection Development, Acquisitions, Catalog, Circulation, Library Operations, and User"; and "Acquisitions, "On-the-Shelf." bined branches, such as circulation and library operations. ${ }^{18}$ Variant terminology has occasionally been used-e.g., "selection" for "acquisitions" or "retrieval" for the "user" finding the document on the shelf. ${ }^{19}$ Each of the branches described above represents a barrier to the user locating a sought-after book or item. Failures in different branches have been variously termed as "dissatisfactions," "errors," or "malfunctions" throughout the literature.

ARL published a detailed manual by Kantor explaining the implementation of his branching method, and some collection evaluation and library performance guides or textbooks, such as one by Hall, have provided succinct summaries of the technique..$^{20}$ During the 1980s, doctoral dissertations using Kantor's method were completed at Case Western Reserve University by Kuraim, Ajlan, Abduljalil, and Rashid, as well as at Rutgers by Ciliberti. ${ }^{21}$ Kantor's branching analysis has also been applied in master's papers or theses written at the University of North Carolina at Chapel Hill by Roberts and Chandler, the University of the Punjab in Pakistan by Bashir, and the University College of Wales by Salter. ${ }^{22}$

The fact that Kantor's branching method has been implemented in the United States, Europe, Africa, Asia, the Middle East, and Australia testifies to its wide international acceptance. In the United States, not counting studies already covered in Mansbridge's literature review, it has been used at

- the University of Illinois Health Sciences Center by Kolner and Welch;

- the William Patterson College Library by Ciliberti et al., and Mitchell, Radford, and Hegg;

- the University of California at Santa Cruz Library by Ferl and Robinson; and

- the San Jose State University by Thorne and Whitlatch. ${ }^{23}$

Internationally, it has been utilized at

- a Tokyo city library system in Japan in a severely modified form by Tamura and Sakai;
- Liverpool Polytechnic Library Service in the United Kingdom twice by Revill;

- the Friesland Provincial Library in the Netherlands by Lieshout;

- the University of the Punjab in Pakistan by Rehman and Bashir;

- the University of Western Australia by Harris and Garner;

- the University of Münster in Germany by Boekhorst;

- the International Islamic University in Malaysia by Rehman, Arif, and Chaudhry;

- the King Fahd University of Petroleum and Minerals in Saudi Arabia by Chaudhry and Ashoor;

- the University of Zululand in South Africa by Zondi;

- four universities in the state of Tamil Nadu in India by Urs and Dominic; and

- a simulated study at the University of Cape Town Medical Library by Steynberg and Rossouw. ${ }^{24}$

Kantor's method has been primarily used for knownitem searches by actual patrons in academic libraries, although it also has been employed in

- the Shaker Heights Senior High School and Cleveland Heights High School libraries in Ohio by Abduljalil;

- the Cleveland Heights-University Heights Main Public Library by Wood, Bremer, and Saraidaridis and by Kuraim;

- the Cameron Village Regional Library in North Carolina in a simulated study by Chandler; and

- a Tokyo city library system by Tamura and Sakai. ${ }^{25}$

While the method has primarily been used to measure book availability to actual patrons, it has also tested the availability of

- journal articles at the University of New Mexico by Bachmann-Derthick and Spurlock;

- journal articles at Adelphi University by Ciliberti et al.;

- journal articles at the University of North Carolina Health Sciences Library by Shaw-Kokot and Varre;

- both books and articles at the University of Western Australia by Harris and Garner; and

- both books and articles at the King Fahd University of Petroleum and Minerals by Chaudhry and Ashoor. ${ }^{26}$

Kantor's method has also been employed for analysis of subject searching at William Patterson College by Ciliberti et al., plus Mitchell, Radford, and Hegg; and at Adelphi University by Cilibert et al. ${ }^{27}$ 


\section{Other Approaches to the Study of Availability}

Various availability tests have been developed as performance or so-called "output" measures for public libraries. Performance Measures for Public Libraries, by De Prospo, Altman, and Beasley, proposed and tested in twenty U.S. public libraries a simulated shelf availability measure using samples of book titles from the American Book Publishing Record and each library's shelflist plus periodical articles selected from leading indexes. ${ }^{28}$ Output Measures for Public Libraries, by Van House et al., includes three availability measures according to type of search: the Title Fill Rate, the Subject and Author Fill Rate, and the Browsers' Fill Rate. ${ }^{29}$ The "title fill rate," as a known-item search, is essentially equivalent to the author-title searches generally used by those implementing Kantor's method. Output Measures for Public Library Service to Children, by Walter, contains a "children's fill rate," "homework fill rate," and "picture book fill rate. ${ }^{30}$ Its companion volume of output measures for young adult services incorporates a "young adult fill rate" and a "homework fill rate." ${ }^{31}$ While some public libraries have simply posted availability scores on the Web without reporting details of the study, this review is limited to formal research reports (e.g., Simpson at the Pikes Peak Library District and Thompson at Augustana College Library). ${ }^{32}$

A few studies have calculated availability based on patron known-item searches without using Kantor's branching analysis or explicit "fill rates," such as those conducted at Macquarie University in Australia by Knox and Wivell, and at Cardiff University in the United Kingdom by Wall and Williams. ${ }^{33}$ Simulated availability studies not involving actual patrons have been conducted at the University of Illinois at Urbana-Champaign by Stelk and Lancaster, the University of Cape Town by Steynberg and Rossouw, and the Cameron Village Regional Library in North Carolina by Chandler. ${ }^{34}$ In addition, simulated investigations have supplemented "real" studies at the Cleveland Heights-University Heights Main Public Library by Kuraim, and the King Faud University of Petroleum and Minerals by Chaudhry and Ashoor. ${ }^{35}$

\section{Accessibility Studies}

Related, yet distinct from availability, is the concept of accessibility, which measures the amount of time required to obtain a document (from either internal or external resources) rather than its immediate availability. Similar to availability, the term "accessibility" is sometimes used inconsistently in the literature. The best-known accessibility measure was developed during the late 1960s and early 1970s, and has entered LIS lore as "Orr's Document Delivery Test" (DDT) ${ }^{36}$ In this technique, the time required to obtain a sample of approximately 300 documents is used to calculate a Capability Index ranging from 0 -no documents available within a week - to 100-all documents available within
10 minutes — which would be considered availability. Orr's test has been implemented in 92 U.S. medical libraries by Orr and Schless; 2 Canadian LIS libraries by Penner; 13 California secondary school libraries by Greenberg; and 7 South African medical libraries by Steynberg and Rossouw. ${ }^{37}$ Although Orr's DDT was not used, the comparative accessibility of books through recall or interlibrary loan was recently investigated at Iowa State University by Gregory and Pedersen. ${ }^{38}$ Tangential to document delivery tests are the numerous performance evaluations of interlibrary loan and commercial document delivery, which include "turnaround" or delivery time as an important variable. This author tabulated the results from approximately 30 such studies published during the $1990 \mathrm{~s} .{ }^{39}$ It is beyond this paper's scope to analyze the results of accessibility studies.

\section{An Analysis of Availability Studies Conducted During the Previous 20 to 25 Years}

This section analyzes the results of the availability studies issued since Mansbridge's literature review (the cutoff date was 1984) as well as a small number of studies published between 1980 and 1984 not included in Mansbridgemainly Ph.D. dissertations, a format he did not address. Appendix A summarizes 46 investigations of availability based on actual clients conducting known-item searches that were published from 1980 to 2001, listing the author, publication date (or degree date for dissertations), institution, sample size, the number of successful searches, and the overall availability rate. For the purpose of consistency and accurate comparison, the availability percentages have been calculated by the author to the first decimal point based on the data reported by the original researchers. Recalculation of the initially reported percentage was sometimes necessary due to inconsistent practice in rounding off numbers by some researchers, inexplicable errors in the originally reported percentage, or cases in which the researchers derived a final percentage by multiplying the percentage results at each branch (the method used by Kantor) rather than by simply dividing the number of successes by the total number of searches. Instances in which the percentage in appendix A differs by more than half a percentage from that which was initially reported are noted in footnotes to the appendix.

Examination of appendix A reveals that overall availability ranged from 33.8 percent at the University of Münster to 83.8 percent at Cardiff University. The high rate at the latter can probably be attributed to the study's focus on "short loan," items-i.e., "reserve" in North American terminology. Twenty-nine of the 46 reported results showed an availability rate in the $50 \mathrm{~s}$ or $60 \mathrm{~s}$ percentage range. The unweighted mean availability rate (with each of the 46 percentages 
counting equally) is 61.3 percent, a figure remarkably similar to the 61 percent reported by Mansbridge, who used this method for calculating the mean. ${ }^{40}$ However, Mansbridge found a larger range in the results from different studies ( 8 to 89 percent). ${ }^{41}$ This literature review's weighted mean (a calculation method not used by Mansbridge that factors in the size of each investigation) was 63.1 percent $(17,801.3$ successes in 28,207 searches) for 43 investigations. Excluded from calculation of the weighted mean were Simpson's two surveys at the Pikes Peak Library District (for which the raw data is unavailable) as well as Jacobs and Young's University of Sussex research, where the 99,778 searches would badly skew the overall average. The 61 or 63 percent mean availability rates found in this review are a bit higher than the general 50 to 60 percent range cited by Bachmann-Derthick and Spurlock; Lieshout; Ciliberti et al.; and Chandler. ${ }^{42}$

The three cases focusing exclusively on serial or journal articles, Bachmann-Derthick at the University of New Mexico, Roberts at East Tennessee State, and Ciliberti et al. at Adelphi University, found lower-than-average availability rates, 55.7 percent, 54.5 percent, and 44.9 percent, respectively. ${ }^{43}$ Among the investigations addressing multiple formats, Chaudhry and Ashoor's study at King Fahd University reported a 58.6 percent availability rate for journal articles, while Harris and Garner found a 54 percent serials availability rate at the University of Western Australia. ${ }^{44}$ While these data might lead to a facile assumption of a lower general availability rate for serials (and a confirmation of the longstanding perception that serials cause difficulties), in the final analysis, the number of cases involving serials is too small to allow firm conclusions.

As indicated in appendix A's footnotes, three studies measured the availability rate before and after librarian intervention. (Note that the vast majority of availability studies have not included librarian assistance as a factor in the equation, so only the initial result is included in appendix A's final column.) A librarian's help increased availability at the Cleveland Heights-University Heights library from 52.4 to 60.8 percent (Kuraim's study), at the Cleveland Health Sciences Library from 59.6 to 63.5 percent (Rashid's study), and from 62.8 to 68.5 percent at the King Fahd University of Petroleum and Minerals (Chaudhry and Ashoor's study). ${ }^{45}$ These investigations suggest, as one would intuitively think, that librarian assistance does result in somewhat higher availability.

The small number of subject-based availability studies (not tabulated in appendix A) display less variation in their availability rates than was apparent in the known-item searches, although the results were comparable. Overall availability was 56.8 percent (108 of 190 searches) and 62 percent (31 of 50 searches) at William Patterson College and 62.2 percent (153 of 246 searches) at Adelphi University or 60 percent, as reported by Ciliberti et al., if the avail- ability rates at each of Kantor's branches are multiplied by each other. ${ }^{46}$

Following appendix A’s format, appendixes B through G summarize availability at each of Kantor's branches, covering respectively, the bibliographic citation, acquisitions, the catalog, circulation, library operations, and the user. While the fractional results occasionally reported in these appendixes may seem counterintuitive, they are easily explained by the location of one volume of a multivolume title, or the use (in a few studies) of a "correction factor" to distribute proportionately among the branches failed searches for which the precise cause could not be determined. Not represented in these appendixes are the investigations that did not employ Kantor's branching technique plus the reports by Zondi as well as Thorne and Whitlatch, where useable data were not presented. ${ }^{47}$

Appendix B shows a consistently high level of availability at the bibliographic branch, ranging from 94.9 to 100 percent. The unweighted mean availability for the nine reported cases is 97.1 percent, while the weighted mean is 97.7 percent (6,990 of 7,154 searches were successful). Failures in this branch were usually due to incorrect citations for the author or the title.

Appendix C tabulates 33 reported cases of availability at the acquisitions branch - the branch most frequently included in studies employing Kantor's methodology. While availability ranged from 66.1 to 97.2 percent, it exceeded 90 percent in the majority of instances (17 of 33) and was more than 80 percent on all but six occasions. It is noteworthy that the two lowest availability rates, 68 percent and 66.1 percent, appear in studies of journal articles by Roberts at East Tennessee State University and Ciliberti et al. at William Patterson College ${ }^{48}$ However, the findings from the other two studies focusing on journal articles, BachmannDerthick and Spulock at the University of New Mexico (85.2 percent) and Shaw-Kokot and Varre at the University of North Carolina at Chapel Hill (94.4 percent), are generally consistent with the other results in the appended table. ${ }^{49}$ The unweighted mean availability rate for these 33 reported results at the acquisitions branch is 87.1 percent and the weighted mean for 32 cases (all but Revill's 1988 study at the Liverpool Polytechnic Library Service, which reported availability percentages but no raw data for the branches) is 89.6 percent with 19,080 successes among 21,299.9 soughtafter items. ${ }^{50}$ At the sub-branch level, the predominant reason for failure was the fact the library had not acquired the item. Other causes of acquisitions failure included weeding, cancellation, the sought-after item's location in a different branch, the item having been declared missing, and an "on order" title having not been received.

Appendix D demonstrates a high success rate at the catalog branch, with the reported availability percentages running from 86.4 to 99.6 percent. Indeed, the rate was 
more than 90 percent in 20 of 21 instances and more than 95 percent in more than half the cases (11 of 21). The unweighted mean availability rate was 94.7 percent and the weighted mean 96.5 percent $(13,328.4$ of 13,806). Appendix D's footnotes show that librarian assistance increased availability at this branch at the Cleveland Heights-University Heights Public Library from 93.4 to 98.8 percent (Kuraim's study) and at the Cleveland Health Science Library from 96.9 to 98.6 percent (Rashid's study) ${ }^{51}$ Frequent reasons for catalog branch failure were inability to locate the record in the catalog as well as transcription of an incorrect call number or an incorrect location.

Despite early studies identifying circulation as a major barrier to book availability, success rates in the circulation branch, presented in appendix E, exceeded 80 percent in all but four instances, ranging from 66.2 to 100 percent. The circulation branch's unweighted mean availability rate for 31 reported results was 87.9 percent and the weighted mean for 30 cases, excluding Revill's 1988 study, was 87.4 percent $(16,899.73$ of $19,337.7) .{ }^{52}$ It is noteworthy that each of the three investigations of journal articles found high availability rates in this branch: Bachmann-Derthick and Spurlock (96.7 percent), Roberts (97.5 percent), and Ciliberti et al. (100 percent), possibly reflecting the fact that journals are less likely to circulate. ${ }^{53}$ As would be expected, the overwhelming majority of circulation failures were attributable to the item being checked out by a patron while another reason was checkout for interlibrary loan purposes.

Appendix F's tabulation of 31 availability rates in the library operations branch shows a range from 65.7 to 98.9 percent with more than half (18) exceeding 90 percent and only four less than 80 percent. This branch's unweighted mean availability rate is 88.8 percent, and the mean weighted rate, for one less case with the 1988 Revill study not counted, stands at 89.9 percent $(15,185.6$ successes in $16,889.73$ attempts).$^{54}$ Of library branch failures, major causes of error were missing items, bindery operations, reshelving operations, misshelved items, and items in technical processing.

Appendix $\mathrm{G}$ tabulates success rates at the user branch as defined and reported by the original investigators. This branch almost always includes user failure to locate the item on the shelf, but may also include user failure with the bibliographic citation or in the catalog. Ranging from 77.7 to 96.6 percent, the user success rate exceeded 90 percent in 18 of the 32 reported results and was less than 80 percent only once. Both the unweighted means (32 instances) and the weighted means (31 instances with 13,833 satisfactions out of $15,413.8$ searches) equal 89.7 percent. A high proportion of user errors was due to the inability to locate the item on the shelf, while another cause of failure was the user not understanding the classification system.

Whereas appendixes B through G summarize success rates in each branch, appendix $\mathrm{H}$ analyzes failures by branch, indicating for the various studies the number and percentage of failures attributed to each branch. In order to provide a more accurate estimation of total user failure, appendix H's user column combines the results from appendix B (user bibliographic failure), appendix D (user failure at the catalog), and appendix $\mathrm{G}$ (user failure at the shelf or overall user failure). The findings have been calculated by the author from the original researchers' raw data.

Within each branch, appendix $\mathrm{H}$ shows wide variation in the proportion of failures attributable to the branch, ranging from 5.9 to 70.4 percent in acquisitions; 0 to 50 percent in circulation; 1.4 to 46.4 percent in library operations; and 6.7 to 42.9 percent for the user. Of $8,991.7$ total failures, 25.3 percent were in the acquisitions branch; 27.1 percent in circulation; 19.0 percent in library operations; 24.7 percent by the user; and 3.9 percent were not solely attributable to any of these branches. Disregarding the four investigations (Wood, Bremer, and Saraidaridis; Kuraim; Tamura and Sakai; and Jacobs' fall survey) that did not include all of these branches, the largest portion of failures was caused by the circulation branch in eleven cases; the acquisitions branch in eight cases; and library operations and the user in five cases each. ${ }^{55}$ While Mansbridge concluded that circulation and library operations were the largest source of book unavailability in academic libraries, this analysis found that the highest percentages of total failures were in the acquisitions and user branches, and that the circulation and acquisitions branches were the largest cause of failures in the most cases. ${ }^{56}$ However, it is apparent from careful review of the data that no branch emerges as the major obstacle to availability.

Appendix I summarizes the results of simulated studies that did not involve actual patrons. Note that Kuraim as well as Chaudhry and Ashoor included both real and simulated components in their research projects. ${ }^{57}$ Availability ranged from 13 to 84 percent with an unweighted mean of 61.8 percent and a weighted mean of 60.6 percent $(2,010$ successes out of 3,315) — figures quite similar to the averages for real studies. One would intuitively anticipate a higher availability rate in a simulated study because user errors would be eliminated and, when a shelflist sample is being used, the items would already have been acquired by the library. Indeed, when the one outlier (the 13 percent availability in Kuraim's sample from the American Book Publishing Record) is disregarded, the mean availability rates increase to 68.8 percent (unweighted) and 69.1 percent (weighted with 1,945 of 2,815 on the shelf). ${ }^{58}$

Finally, many of these studies have addressed subsidiary issues beyond the scope of this analysis, such as

- whether user type (student or faculty, full or parttime student, and so on) is a variable influencing the ability to locate items;

- comparison of the performance of different libraries; and 
- longitudinal comparisons within a single library. ${ }^{59}$

\section{Summary}

This literature review and analysis of more than fifty specific investigations of availability found that the majority used Kantor's branching method (but numerous combinations of branches), were implemented in academic libraries (with some in public and school libraries), and were for knownitem searches by actual patrons. About half the studies were conducted in U.S. libraries with the remainder carried out in ten other countries.

There is considerable variation among libraries in overall availability as well as availability in different branches. One of the values of these studies is the identification of reasons for lack of availability in a specific library context. Branch-level analysis shows that availability at each branch only occasionally falls below 80 percent and frequently exceeds 90 percent. Moreover, no branch stands out as the major bottleneck or barrier to availability. This study, in conjunction with Mansbridge's review, demonstrates that, in a print environment, patrons on average find what they are looking for only slightly more than 60 percent of the time. An obvious question concerns what the availability rate would be for electronic resources on the Web or licensed by a library.

\section{A New Definition of Availability}

More than a decade ago, Kaske argued that the availability concept was no longer applicable to the then current environment because user needs were often met through externally-procured print items. He advocated the development of a new availability model that would incorporate the searching of multiple libraries and the time the user could wait to obtain the item. ${ }^{60}$

Expanding upon Kaske, this paper maintains that the traditional availability concept reviewed here can be adopted with modification for an electronic environment to measure user success in immediately obtaining soughtafter items on the Web or in the proprietary e-resources licensed by a particular library. While many patrons may no longer expect the immediate gratification of finding an item on a library shelf, they may nevertheless expect immediate gratification in locating it electronically. The extent to which they are successful in doing so can serve as an objective, user-centered evaluation and performance measure in the newly emerging electronic environment. Such tests could also identify barriers to user success and facilitate the design of better electronic systems.

A detailed outline of the procedures for conducting an electronic availability study is beyond this paper's scope. As with traditional availability studies, the method would work best for known-item searches by real users, although a simulated study would be a possibility.

\section{Future Research}

Future research issues regarding electronic availability studies include

- development of a method for measuring availability of electronic resources;

- determination of an expected standard for availability rates in an electronic environment;

- comparison of electronic availability rates with those reported in the numerous studies conducted in traditional print environments; and

- identification of the major barriers to electronic availability and the relative success rates at the various barriers.

One might hypothesize the following potential barriers or branches: the item is not on the Web; the URL has changed; the item is only available in a proprietary database that is not licensed by the user's library; the maximum licensed number of simultaneous users are logged on; technological failure, such as a server is down or the local power off; and the user is unable to locate an otherwise available item. Many of the issues that have been investigated in typical availability studies could be addressed in an electronic availability study. Examples would include

- comparative availability among different user groups;

- comparative availability among libraries;

- longitudinal comparison within a library;

- the impact of professional assistance to the user upon availability; and

- the impact of policy changes on availability.

Finally, one could design and conduct electronic accessibility tests, modeled on Orr's DDT, to ascertain the time requited to obtain electronic documents.

\section{Conclusions}

While availability studies are sometimes viewed as a research approach from the 1970s and 1980s, this literature review has demonstrated their continued use on an international scale throughout the 1990s and into the twenty-first century. ${ }^{61}$ Although developed for a print environment, the issues 
investigated in an availability study are equally relevant to an electronic environment. Mansbridge contended that an availability study could be used for nonlibrary purposes, such as analyzing the availability of audio-visual equipment in an academic setting. ${ }^{62}$ If, at some future point, libraries cease to exist or are radically transformed into now unrecognizable entities, an electronic availability study could still be employed in an academic institution as an objective, usercentered evaluation measure to help assess how effectively faculty and student information needs are being met.

\section{References and Notes}

1. Barbara Lockett, Guide to the Evaluation of Library Collections (Chicago and London: ALA, 1989).

2. A. N. Zainab and S. L. Ng, "Availability and Overlap of Quality Computer Science Journal Holdings in Selected University Libraries in Malaysia," Malaysian Journal of Library of Information Science 8, no. 1 (Jul. 2003): 45-63; John Mutter, Jim Milliot, and Karen Holt, "What Price Used Books?" Publishers Weekly 251, no. 39 (Sept. 27, 2004): 31-34.

3. Paul B. Kantor, Objective Performance Measures for Academic and Research Libraries (Washington, D.C.: ARL, 1984), v.; D. H. Revill, "An Availability Survey in Cooperation with a School of Librarianship and Information Studies," Library Review 37, no. 1 (1988): 17.

4. An approximate quotation from Herbert S. White's presentation at Indiana University's School of Library and Information Science, May 9, 2003.

5. Lynn B. Chandler, "Book Availability in the Cameron Village Regional Library" (master's paper, University of North Carolina at Chapel Hill, 1998), 2.

6. N. A. Jacobs and R. C. Young, "Measuring Book Availability in an Academic Library: A Methodological Comparison," Journal of Documentation 51, no. 3 (Sept. 1995): 281-90; Anne Ciliberti et al., "Empty Handed? A Material Availability Study and Transaction Log Analysis Verification," Journal of Academic Librarianship 24, no. 4 (Jul. 1998): 282-89.

7. F. W. Lancaster, If You Want to Evaluate Your Library ..., 2nd ed. (Champaign, Ill.: University of Illinois, Graduate School of Library and Information Science, 1993), 222.

8. Lockett, Guide to the Evaluation of Library Collections, 1112; Jan Bachmann-Derthick and Sandra Spurlock, "Journal Availability at the University of New Mexico," in Advances in Serials Management, vol. 3, eds. Jean G. Cook and Marcia Tuttle (Greenwich, Conn.: JAI Pr., 1989), 174.

9. H. V. Gaskill, R. M. Dunbar, and C. H. Brown, "An Analytical Study of the Use of a College Library," Library Quarterly 4, no. 4 (Oct. 1934): 581.

10. Michael K. Buckland, Book Availability and the Library User (New York: Pergamon, 1975).

11. John Mansbridge, "Availability Studies in Libraries," Library \& Information Science Research 8, no. 4 (Oct./Dec. 1986): 299-314.

12. Paul B. Kantor, "Availability Analysis," Journal of the American Society for Information Science 27 (Sept./Oct. 1976): 31119.
13. Judith B. Wood, Julius J. Bremer, and Susan A. Saraidaridis, "Measurement of Service at a Public Library," Public Library Quarterly 2, no. 2 (Summer 1980): 49-57; Faraj Mohamed Kuraim, "The Principal Factors Causing Reader Frustration in a Public Library" (Ph.D. diss., Case Western Reserve University, 1983).

14. Haseeb F. Rashid, "Book Availability as a Performance Measure of a Library: An Analysis of the Effectiveness of a Health Sciences Library," Journal of the American Society for Information Science 41, no. 7 (Oct. 1990): 501-7.

15. Anne C. Ciliberti et al., "Materials Availability: A Study of Academic Library Performance," College \& Research Libraries 48, no. 6 (Nov. 1987): 513-27; Eugene S. Mitchell, Marie L. Radford, and Judith L. Hegg, "Book Availability: Academic Library Assessment," College \& Research Libraries 55, no. 1 (Jan. 1994): 47-55; Ciliberti et al., "Empty Handed? A Material Availability Study."

16. Stuart J. Kolner and Eric C. Welch, "The Book Availability Study as an Objective Measure of Performance in a Health Sciences Library," Bulletin of the Medical Library Association 73, no. 2 (Apr. 1985): 121-31; D. H. Revill, “Availability” as a Performance Measure for Academic Libraries," Journal of Librarianship 19, no. 1 (Jan. 1987): 14-30; Elaine Salter, "How Good is the Library Provision in FE Colleges?" Library Association Record 95 (June 1993): 348-49; Abdus Sattar Chaudhry and Saleh Ashoor, "Comprehensive Materials Availability Studies in Academic Libraries," Journal of Academic Librarianship 20, no. 5-6 (Nov. 1994): 300-305; Lindiwe E. Zondi, "Measuring Availability and Nonavailability Rates at the University of Zululand Library," South African Journal of Library \& Information Science 64, no. 2 (June 1996): 108-13; Shalini R. Urs and J. Dominic, "Quality in Collection Management: Measuring Book Availability Performance of Academic Libraries" (paper presented at the DRTC Workshop on Information Management, 6-8 January 1999), http://64.233.167.104/search?q=cache:16vCnbBnB-gJ: https://drtc.isibang.ac.in/retrieve/257/Papah.pdf+Kantor++br anching\&hl=en (accessed Sept. 20, 2005); Mohamed Fituri Abduljalil, "Book Availability and User Satisfaction in School Libraries: A Case Study of Shaker Heights Senior High School and Cleveland Heights High School" (Ph.D. diss., Case Western Reserve University, 1985); Terry Ellen Ferl and Margaret G. Robinson, "Book Availability at the University of California, Santa Cruz," College \& Research Libraries 47, no. 5 (Sept. 1986): 501-8; Bachmann-Derthick and Spurlock, "Journal Availability at the University of New Mexico"; Jennifer Eugenie Roberts, "Journal Availability Study" (master's paper, University of North Carolina at Chapel Hill, 1989); Melanie Harris and Imogen Garner, "Using an Availability Survey to Improve Service at a University Library," Australian Academic \& Research Libraries 23, no. 1 (Mar. 1992): 25-34; Sajjad Ur Rehman and Shaneena Bashir, "Comparative Measurement of Book Availability in Academic Libraries," International Information \& Library Review 25 (Sept. 1993): 183-93; Sajjad Ur Rehman, Kokab Arif, and Abdus Sattar Chaudhry, "Availability Analysis: Conduct, Comparison and Applications," Australian Academic \& Research Libraries 
25 (Mar. 1994): 19-26; Alan M. Ajlan, "The Effectiveness of Two Academic Libraries in Saudi Arabia: An Enquiry into the Main Factors Affecting Their Services" (Ph.D. diss., Case Western Reserve University, 1985); Ciliberti et al., "Materials Availability: A Study of Academic Library Performance"; N. A. Jacobs, "The Evaluation and Improvement of Book Availability in an Academic Library," New Review of Academic Librarianship 1 (1995): 41-55; Mitchell, Radford, and Hegg, "Book Availability: Academic Library Assessment"; Julia ShawKokot and Claire de la Varre, "Using a Journal Availability Study to Improve Access," Bulletin of the Medical Library Association 89, no. 1 (Jan. 2001): 21-28.

17. B. M. M. Lieshout, "Over de Beschikbaarheid van Literatuur: Verslag van een Availability Studie, Uitgevoerd in de Provinciale Bibliotheek van Friesland," Open 24 (Mar. 1992): 86-89; Rashid, "Book Availability as a Performance Measure of a Library: An Analysis of the Effectiveness of a Health Sciences Library;" Shunsaku Tamura and Yumiko Sakai, "Materials Availability Study in Public Libraries," Library o Information Science 21 (1983): 49-69.

18. Wood, Bremer, and Saraidaridis, "Measurement of Service at a Public Library;" Kuraim, "The Principal Factors Causing Reader Frustration in a Public Library."

19. Mitchell, Radford, and Hegg, "Book Availability: Academic Library Assessment"; Ciliberti et al., "Materials Availability: A Study of Academic Library Performance"; Mitchell, Radford, and Hegg, "Book Availability: Academic Library Assessment."

20. Kantor, Objective Performance Measures for Academic and Research Libraries; Blaine H. Hall, Collection Assessment Manual for College and University Libraries (Phoenix, Ariz.: Oryx, 1985): 43-51.

21. Kuraim, "The Principal Factors Causing Reader Frustration in a Public Library"; Ajlan, "The Effectiveness of Two Academic Libraries in Saudi Arabia"; Abduljalil, "Book Availability and User Satisfaction in School Libraries"; Haseeb F. Rashid, "Factors Affecting User Satisfaction in a Medical Library and a Comparison with other Types of Libraries" (Ph.D. diss., Case Western Reserve University, 1985). This paper analyzes data from Rashid, "Book Availability as a Performance Measure of a Library: An Analysis of the Effectiveness of a Health Sciences Library," which was based on this dissertation; Anne C. Ciliberti, "The Development and Methodological Study of an Instrument for Measuring Material Availability in Libraries" (Ph.D. diss., Rutgers, the State University of New Jersey, 1985). This paper analyzes data from Ciliberti et al., "Materials Availability: A Study of Academic Library Performance," which was apparently based on this dissertation.

22. Roberts, "Journal Availability Study"; Chandler, "Book Availability in the Cameron Village Regional Library"; Shaneena Bashir, "Measurement of Book Availability at the Punjab University Library” (master’s thesis, University of the Punjab, 1991) This item was not examined by the author. This paper analyzes data from Rehman and Bashir, "Comparative Measurement of Book Availability in Academic Libraries," which was apparently based on Rehman's thesis; Elaine
Salter, "The Evaluation of Library Service Effectiveness with Particular Reference to Further Education" (mlib. thesis, University College of Wales, 1992). This item was not examined by the author. This paper analyzes data from Salter, "How Good is the Library Provision in FE Colleges?", which was based on her thesis.

23. Kolner and Welch, "The Book Availability Study as an Objective Measure of Performance in a Health Sciences Library"; Ciliberti et al., "Materials Availability: A Study of Academic Library Performance"; Mitchell, Radford, and Hegg, "Book Availability: Academic Library Assessment"; Ferl and Robinson, "Book Availability at the University of California, Santa Cruz"; Rosemary Thorne and Jo Bell Whitlatch, "Patron Online Catalog Success," College \& Research Libraries 55, no. 6 (Nov. 1994): 479-97.

24. Tamura and Sakai, "Materials Availability Study in Public Libraries”; Revill, “Availability” as a Performance Measure for Academic Libraries"; Revill, "An Availability Survey in Cooperation with a School of Librarianship and Information Studies," 17-34; Lieshout, "Over de Beschikbaarheid van Literatuur"; Rehman and Bashir, "Comparative Measurement of Book Availability"; Harris and Garner, "Using an Availability Survey to Improve Service at a University Library"; Peter te Boekhorst, "Methoden der Leistungsmessung in Bibliotheken: Die Durchführung einer Verfügbarkseitstudie an der UB Munster," Bibliothek Forschung und Praxis 16, no. 2 (1992): 153-61; Rehman, Arif, and Chaudhry, "Availability Analysis: Conduct, Comparison and Applications"; Chaudhry and Ashoor, "Comprehensive Materials Availability Studies"; Zondi, "Measuring Availability and Nonavailability Rates at the University of Zululand Library"; Urs and Dominic, "Quality in Collection Management"; S. Steynberg and S. F. Rossouw, "The Availability of Research Journals in South African Academic Medical Libraries," South African Medical Journal 83 (Nov. 1993): 837-39.

25. Abduljalil, "Book Availability and User Satisfaction in School Libraries"; Wood, Bremer, and Saraidaridis, "Measurement of Service at a Public Library"; Kuraim, "The Principal Factors Causing Reader Frustration in a Public Library”; Chandler, "Book Availability in the Cameron Village Regional Library"; Tamura and Sakai, "Materials Availability Study in Public Libraries."

26. Bachmann-Derthick and Spurlock, "Journal Availability at the University of New Mexico"; Ciliberti et al., "Empty Handed? A Material Availability Study"; Shaw-Kokot and Varre, "Using a Journal Availability Study"; Harris and Garner, "Using an Availability Survey to Improve Service at a University Library"; Chaudhry and Ashoor, "Comprehensive Materials Availability Studies."

27. Ciliberti et al., "Materials Availability: A Study of Academic Library Performance"; Mitchell, Radford, and Hegg, "Book Availability: Academic Library Assessment"; Ciliberti et al., "Empty Handed? A Material Availability Study."

28. Ernest R. DeProspo, Ellen Altman, and Kenneth E. Beasley, Performance Measures for Public Libraries (Chicago: PLA, 1973), 31-36. 
29. Nancy A. Van House et al., Output Measures for Public Libraries: A Manual of Standardized Procedures, 2nd ed. (Chicago: ALA, 1987), 59-62.

30. Virginia A. Walter, Output Measures for Public Library Service to Children: A Manual of Standardized Procedures (Chicago: ALA, 1992), 42-50.

31. Virginia A. Walter, Output Measures and More: Planning and Evaluating Public Library Services for Young Adults (Chicago: ALA, 1995), 61-67.

32. Susan Simpson, "Materials Availability/Fill-Rate Study at Pikes Peak Library District," Colorado Libraries 16, no. 1 (Mar. 1990): 18-19; Ronelle K. H. Thompson, "How Are We Doing? Using a Materials Availability Survey in an Academic Library," in Libraries and the Literacy Challenge: The Frontier of the 90s; Proceedings of the Mountain Plains Library Association Academic Library Section Research Forum; MPLA/NDLA/SDLA Joint Conference, Sept. 23-26, 1987, Bismarck, ND, ed. V. Sue Hatfield (Emporia, Kans.: Emporia State Univ., 1987), 17-30.

33. Jeanette Knox and Carolyn Wivell, "Success Rates at Macquarie University Library," Australian Academic \& Research Libraries 19, no. 1 (Mar. 1988): 25-31; Terry Wall and Jan Williams, "Availability, Accessibility, and Demand for Recommended Books in Academic Libraries," Journal of Librarianship \& Information Science 31, no. 3 (Sept. 1999): 145-51.

34. Roger Edward Stelk and F. W. Lancaster, "The Use of Shelflist Samples in Studies of Book Availability," Collection Management 13, no. 4 (1990): 19-24; Steynberg and Rossouw, "The Availability of Research Journals;" Chandler, "Book Availability in the Cameron Village Regional Library."

35. Kuraim, "The Principal Factors Causing Reader Frustration in a Public Library"; Chaudhry and Ashoor, "Comprehensive Materials Availability Studies."

36. Richard H. Orr et al., "Development of Methodologic Tools for Planning and Managing Library Services, II: Measuring a Library's Capability for Providing Documents," Bulletin of the Medical Library Association 56, no. 3 (Jul. 1968): 241-67; Richard H. Orr and Arthur P. Schless, "Document Delivery Capabilities of Major Biomedical Libraries in 1968: Results of a National Survey Employing Standardized Tests," Bulletin of the Medical Library Association 60, no. 3 (Jul. 1972): 382-422.

37. Ibid.; Rudolf Jacob Penner, "Measuring a Library's Capability," Journal of Education for Librarianship 13, no. 1 (Summer 1972): 17-30; Marilyn Werstein Greenberg, "Availability of Library Materials in Thirteen Secondary Schools" (Ph. D. diss., Univ. of Chicago, 1981); Steynberg and Rossouw, "The Availability of Research Journals"; Susan Steynberg and S. F. Rossouw, "Testing Orr's Document Delivery Test on Biomedical Journals in South Africa," Bulletin of the Medical Library Association 83, no. 1 (Jan. 1995): 78-84.

38. David J. Gregory and Wayne A. Pedersen, "Book Availability Revisited: Turnaround Time for Recalls versus Interlibrary Loans," College \& Research Libraries 64, no. 4 (Jul. 2003): 283-99.

39. Thomas E. Nisonger, “Accessing Information: The Evaluation Research,” Collection Management 26, no. 1 (2001): 1-23.

40. Mansbridge, "Availability Studies in Libraries," 307.
41. Ibid., 305.

42. Bachmann-Derthick and Spurlock, "Journal Availability at the University of New Mexico," 173; Lieshout, "Over de Beschikbaarheid van Literatuur," 88; Ciliberti et al., "Empty Handed? A Material Availability Study," 282; Chandler, "Book Availability in the Cameron Village Regional Library," 1.

43. Bachmann-Derthick, "Journal Availability"; Roberts, "Journal Availability Study"; Ciliberti et al., "Empty Handed? A Material Availability Study."

44. Chaudhry and Ashoor, "Comprehensive Materials Availability Studies," 302; Harris and Garner, "Using an Availability Survey to Improve Service at a University Library," 28.

45. Kuraim, "The Principal Factors Causing Reader Frustration in a Public Library"; Rashid, "Book Availability as a Performance Measure of a Library: An Analysis of the Effectiveness of a Health Sciences Library"; Chaudhry and Ashoor, "Comprehensive Materials Availability Studies."

46. Ciliberti et al., "Materials Availability: A Study of Academic Library Performance," 521; Mitchell, Radford, and Hegg, "Book Availability: Academic Library Assessment," 51; Ciliberti et al., "Empty Handed? A Material Availability Study," 284.

47. Zondi, "Measuring Availability and Nonavailability Rates at the University of Zululand Library"; Thorne and Whitlatch, "Patron Online Catalog Success."

48. Roberts, "Journal Availability Study"; Ciliberti et al., "Materials Availability: A Study of Academic Library Performance."

49. Bachmann-Derthick and Spurlock, "Journal Availability at the University of New Mexico"; Shaw-Kokot and Varre, "Using a Journal Availability Study."

50. Revill, "An Availability Survey in Cooperation with a School of Librarianship and Information Studies."

51. Kuraim, "The Principal Factors Causing Reader Frustration in a Public Library"; Rashid, "Book Availability as a Performance Measure of a Library: An Analysis of the Effectiveness of a Health Sciences Library."

52. Revill, "An Availability Survey in Cooperation with a School of Librarianship and Information Studies."

53. Bachmann-Derthick and Spurlock, "Journal Availability at the University of New Mexico"; Roberts, "Journal Availability Study"; Ciliberti et al., "Materials Availability: A Study of Academic Library Performance."

54. Revill, "An Availability Survey in Cooperation with a School of Librarianship and Information Studies."

55. Wood, Bermer, and Saraidaridis, "Measurement of Service at a Public Library"; Kuraim, "The Principal Factors Causing Reader Frustration in a Public Library"; Tamura and Saki, "Materials Availability Study"; Jacobs, "The Evolution and Improvement of Book Availability in an Academic Library."

56. Mansbridge, “Availability Studies in Libraries," 304.

57. Kuraim, "The Principal Factors Causing Reader Frustration in a Public Library"; Chaudhry and Ashoor, "Comprehensive Materials Availability Studies."

58. Kuraim, "The Principal Factors Causing Reader Frustration in a Public Library."

59. Mansbridge, "Availability Studies in Libraries"; Roberts, "Journal Availability Study"; Zondi, "Measuring Availability 
and Nonavailability Rates at the University of Zululand Library"; Abduljalil, "Book Availability and User Satisfaction in School Libraries"; Ajlan, "The Effectiveness of Two Academic Libraries in Saudi Arabia"; Simpson, "Materials Availability/ Fill-Rate Study at Pikes Peak Library District"; Jacobs, "The Evaluation and Improvement of Book Availability"; Mitchell, Radford, and Hegg, "Book Availability: Academic Library Assessment."
60. Neal K. Kaske, "Materials Availability Model and the Internet," Journal of Academic Librarianship 20, no. 5-6 (Nov. 1994): 317-18.

61. Gregory and Pedersen, "Book Availability Revisited," 284.

62. Mansbridge, "Availability Studies in Libraries," 312.

\section{Appendix A. Known-Item Search Availability Rates in Studies Incorporating Library Patrons}

\begin{tabular}{|c|c|c|c|c|c|}
\hline Authors & $\begin{array}{l}\text { Pub. } \\
\text { Year }\end{array}$ & Library & $\begin{array}{l}\text { Number of } \\
\text { Searches }\end{array}$ & Successes & $\begin{array}{l}\text { Percent } \\
\text { Available }\end{array}$ \\
\hline Wood, Bremer, and Saraidaridis ${ }^{1}$ & 1980 & $\begin{array}{l}\text { Cleveland Heights-University Heights Main } \\
\text { Public Library }\end{array}$ & 350 & 132 & 37.7 \\
\hline Kuraim $^{2}$ & 1983 & $\begin{array}{l}\text { Cleveland Heights-University Heights Main } \\
\text { Public Library }\end{array}$ & 500 & $262^{3}$ & 52.4 \\
\hline Tamura and Sakai ${ }^{4}$ & 1983 & a Tokyo city library system & 68 & 54 & 79.4 \\
\hline Abduljalil & 1985 & Cleveland High School & 432 & 203 & 47.0 \\
\hline Abduljalil & 1985 & Shaker Heights High School & 432 & 236 & 54.6 \\
\hline Ajlan & 1985 & King Saud U., Saudi Arabia & 500 & 265 & 53.0 \\
\hline Ajlan & 1985 & U. of Petroleum and Minerals, Saudi Arabia & 500 & 268 & 53.6 \\
\hline Kolner and Welch & 1985 & U. of Illinois Health Sci. Lib.-Peoria & 760 & 447 & 58.8 \\
\hline Kolner and Welch & 1985 & U. of Illinois Health Sci. Lib.-Rockford & 65 & 35 & 53.8 \\
\hline Kolner and Welch & 1985 & U. of Illinois Health Sci. Lib.-Chicago & 60 & 44 & 73.3 \\
\hline Ferl and Robinson & 1986 & U. of California, Santa Cruz & 408 & 250 & 61.3 \\
\hline Ciliberti et al. & 1987 & Willaim Patterson College & 211 & 107 & $50.7^{5}$ \\
\hline Revill & 1987 & $\begin{array}{l}9 \text { site libraries of Liverpool Polytechnic Library } \\
\text { Services, U.K. }\end{array}$ & 1,458 & 1,003 & 68.8 \\
\hline Thompson & 1987 & Augustana College, 1986 survey & 364 & 258 & 70.9 \\
\hline Thompson & 1987 & Augustana College, 1987 survey & 235 & 190 & 80.9 \\
\hline Knox and Wivell & 1988 & Macquarie U., Australia Oct. 9, 1986 survey & 384 & 312 & $81.3^{6}$ \\
\hline Knox and Wivell & 1988 & Macquarie U., Australia Oct. 26, 1986 survey & 290 & 240 & 82.8 \\
\hline Revill & 1988 & $\begin{array}{l}9 \text { site libraries of Liverpool Polytechnic Library } \\
\text { Services, U.K. }\end{array}$ & 2,064 & 1,548 & 75 \\
\hline Bachmann-Derthick and Spulock ${ }^{7}$ & 1989 & U. of New Mexico & 483 & 269 & 55.7 \\
\hline Roberts $^{8}$ & 1989 & East Tennessee U., College of Medicine & 297 & 162 & 54.5 \\
\hline Rashid & 1990 & Cleveland Health Sciences Lib. & 1,000 & $596^{9}$ & 59.6 \\
\hline Simpson & 1990 & Pikes Peak Library District, 1988 survey & Not reported & Not reported & 66 \\
\hline Simpson & 1990 & Pikes Peak Library District, 1989 survey & Not reported & Not reported & 59 \\
\hline Boekhorst & 1992 & U. of Munster, Germany & 751 & 254 & 33.8 \\
\hline Harris and Garner & 1992 & U. of Western Australia, Australia & $589^{10}$ & 259 & 44.0 \\
\hline
\end{tabular}




\begin{tabular}{|c|c|c|c|c|c|}
\hline Authors & $\begin{array}{l}\text { Pub. } \\
\text { Year }\end{array}$ & Library & $\begin{array}{l}\text { Number of } \\
\text { Searches }\end{array}$ & Successes & $\begin{array}{l}\text { Percent } \\
\text { Available }\end{array}$ \\
\hline Lieshout & 1992 & Friesland Provincial Lib., Netherlands & 401 & 227.3 & 56.7 \\
\hline Rehman and Bashir & 1993 & U. of Punjab, Pakistan & 300 & 124 & 41.3 \\
\hline Salter & 1993 & Acton College, U.K & $124^{11}$ & 86 & 69.4 \\
\hline Chaudhry and Ashoor & 1994 & $\begin{array}{l}\text { King Fahd U. of Petroleum and Minerals, Saudi } \\
\text { Arabia }\end{array}$ & $607^{12}$ & $381^{13}$ & 62.8 \\
\hline Mitchell, Radford, and Hegg & 1994 & William Patterson College & 61 & 40 & $65.6^{14}$ \\
\hline Rehman, Arif, and Chaudhry & 1994 & International Islamic U., Malaysia & 441 & 233 & 52.8 \\
\hline Thorne and Whitlatch ${ }^{15}$ & 1994 & San Jose State U., April 1993 & 93 & 61 & 65.6 \\
\hline Thorne and Whitlatch & 1994 & San Jose State U., April 1988 & 499 & 270 & 54.1 \\
\hline Thorne and Whitlatch & 1994 & San Jose State U., April 1983 & 350 & 239 & 68.3 \\
\hline Jacobs & 1995 & U. of Sussex, U.K., spring 1994 survey & 4,103 & 2,566 & 62.5 \\
\hline Jacobs & 1995 & U. of Sussex, U.K., fall 1994 survey & 1,585 & 1,136 & 71.7 \\
\hline Jacobs and Young & 1995 & U. of Sussex, U.K. & $99,778^{16}$ & 75,126 & $75.3^{17}$ \\
\hline Zondi & 1996 & U. of Zululand, South Africa & 353 & 178 & 50.4 \\
\hline Ciliberti, et al. & 1998 & Adelphi U. & 195 & 119 & $61.0^{18}$ \\
\hline $\begin{array}{l}\text { Ciliberti, et al. (journal articles in } \\
\text { CD-ROM index) }\end{array}$ & 1998 & Adelphi U. & $127^{19}$ & 57 & 44.9 \\
\hline Urs and Dominic & 1999 & Anna U., India & 1,254 & 855 & $68.2^{20}$ \\
\hline Urs and Dominic & 1999 & Bharathiar U., India & 870 & 460 & $52.9^{21}$ \\
\hline Urs and Dominic & 1999 & Bharathidasan U., India & 957 & 544 & $56.8^{22}$ \\
\hline Urs and Dominic & 1999 & Tamilnadu Agricultural U., India- & 1,150 & 766 & $66.6^{23}$ \\
\hline Wall and Willaims & 1999 & Cardiff U., U.K. & $480^{24}$ & 402 & 83.8 \\
\hline Shaw-Kokot and Varre ${ }^{25}$ & 2001 & $\begin{array}{l}\text { U. of North Carolina-Chapel Hill-Health } \\
\text { Sciences Lib. }\end{array}$ & 2,056 & 1,663 & 80.9 \\
\hline
\end{tabular}

\section{Notes}

1. Although earlier than the 1984 end point for Mansbridge's literature review, this item was not covered in the review.

2. Not covered in Mansbridge's review.

3. There were 262 successes and a 52.4 percent success rate without librarian assistance increasing to 304 and a 60.8 percent success rate with librarian assistance.

4. Not covered in Mansbridge's review.

5. Overall availability was 53.6 percent for 401 searches, when 190 subject searches were considered.

6. Based on calculation from the raw data of the researchers, who reported a 76.8 percent availability.

7. Journal articles.

8. Journal articles.

9. There were 596 successes and a 59.6 percent success rate without librarian assistance increasing to 635 and a 63.5 percent success rate with librarian assistance.

10. Includes books, reserve items, and serial articles.

11. Results for one day for which complete data was reported. 500 forms were distributed during 5 days, but the number of titles sought is not reported. The five-day availability rate was 70 percent.

12. Includes books and journal articles. When 600 simulated items were also considered, availability was 63.8 percent for 1,207 items.

13. There were 381 successes and a 62.8 percent success rate without librarian assistance increasing to 416 and a 68.5 percent success rate with librarian assistance.

14. Overall availability was 64.0 percent for 111 searches, when 50 subject searches were considered.
15. Thorne and Whitlatch also reported results from April 1979 and April 1976 which are not summarized here because they precede this review's 1980 cut-off point.

16. Patron searches in an online public access catalog.

17. Measured whether books searched for in the OPAC were available for circulation without addressing whether the patron actually located them on the shelf

18. The overall availability rate was 57.9 percent for 568 attempts when subject searches and searches in a CD-ROM journal index are included.

19. Searches for articles in a CD-ROM journal index.

20. Corrected percentage calculated by author from raw data of Urs and Dominic, who reported 66 percent based on multiplying the success rate percentages at the 4 branches.

21. Corrected percentage calculated by author from raw data of Urs and Dominic, who reported 52 percent based on multiplying the success rate percentages at the 4 branches.

22. Corrected percentage calculated by author from raw data of Urs and Dominic, who reported 55 percent based on multiplying the success rate percentages at the 4 branches.

23. Corrected percentage calculated by author from raw data of Urs and Dominic, who reported 64 percent based on multiplying the success rate percentages at the 4 branches.

24. "Short loan" (i.e., reserve) books.

25. Journal articles. 


\section{Appendix B. Availability Rates in Kantor's Bibliographic Branch}

\author{
Authors \\ Kuraim \\ Ajlan, King Saud U. \\ Ajlan, Petroleum and Minerals U. \\ Ciliberti et al. \\ Rashid \\ Mitchell, Radford, and Hegg \\ Jacobs, spring 1994 survey $^{1}$ \\ Ciliberti et al. \\ Cilberti el al., journal articles
}

Pub. Year
1983
1985
1985
1987
1990
1994
1995
1998
1998

Note

1. The term "mis-citations" was used for the bibliographic branch.
Number of

Searches

500

500

500

211

1,000

61

4,103

195

84

$\begin{array}{cc}\text { Successes } & \text { Percent Available } \\ 500 & 100 \\ 491 & 98.2 \\ 476 & 95.2 \\ 206 & 97.6 \\ 949 & 94.9 \\ 59 & 96.7 \\ 4,038 & 98.4 \\ 191 & 97.9 \\ 80 & 95.2\end{array}$




\section{Appendix C. Availability Rates in Kantor's Acquisitions Branch}

\section{Authors}

Wood, Bremer, and Saraidaridis

Kuraim

Tamura and Sakai

Abduljalil, Cleveland Heights

Abduljalil, Shaker Heights

Ajlan, King Saud U.

Ajlan, Petroleum and Minerals U.

Kolner and Welch, Illinois-Chicago

Kolner and Welch, Illinois-Peoria

Kolner and Welch, Illinois-Rockford

Ferl and Robinson

Ciliberti et al.

Revill

Revill

Bachmann-Derthick and Spurlock ${ }^{1}$

Roberts $^{3}$

Rashid

Boekhorst

Harris and Garner

Lieshout

Rehman and Bashir

Salter

Chaudhry and Ashoor

Mitchell, Radford, and Hegg ${ }^{12}$

Rehman, Arif, and Chaudhry

Jacobs, spring 1994 survey

Ciliberti et al.

Ciliberti et al., journal articles

Urs and Dominic, Anna U.

Urs and Dominic, Bharathiar U.

Urs and Dominic, Bharathidasan U.

Urs and Dominic, Tamilnadu U.

Shaw-Kokot and Varre ${ }^{15}$

$\begin{array}{cc}\begin{array}{c}\text { Pub. } \\ \text { Year }\end{array} & \begin{array}{c}\text { Number of } \\ \text { Searches }\end{array} \\ 1980 & 350 \\ 1883 & 500 \\ 1983 & 68 \\ 1985 & 432 \\ 1985 & 432 \\ 1985 & 491 \\ 1985 & 476 \\ 1985 & 760 \\ 1985 & 65 \\ 1985 & 60 \\ 1986 & 408 \\ 1987 & 206 \\ 1987 & 1,458 \\ 1988 & \text { Not Reported } \\ 1989 & 483.2 \\ 1989 & 297 \\ 1990 & 899^{4} \\ 1992 & 751 \\ 1992 & 589^{6} \\ 1992 & 401 \\ 1993 & 299.4 \\ 1993 & 124^{8} \\ 1994 & 606^{10} \\ 1994 & 59 \\ 1994 & 441 \\ 1995 & 4,038^{13} \\ 1998 & 191 \\ 1998 & 127 \\ 1999 & 1,254 \\ 1999 & 870 \\ 1999 & 957 \\ 1999 & 1,150 \\ 2001 & 2,057.30\end{array}$

$2,057.30$

\section{Successes}

287

486

63

389

393

414

450

711.5

56

55

368

185

$1,347.5$

Not Reported

$411.8^{2}$

202

800

521

478

293.5

$250.4^{7}$

117

555

55

390

3,921

171

84

1,195

660

751

1,078

$1,941.3^{16}$
Percent

Available

82.0

97.2

92.6

90.0

91.0

84.3

94.5

93.6

86.2

91.7

90.2

89.8

92.4

92.0

85.2

68.0

89.0

$69.4^{5}$

81.2

73.2

83.6

$94.4^{9}$

$91.6^{11}$

93.2

88.4

97.1

89.5

66.1

95.3

75.9

78.5

$93.7^{14}$

94.4

\section{Notes}

1. Journal articles.

2. Data includes a built-in correction factor for the 31 cases where it was impossible to determine the cause of unavailability.

3. Journal articles.

4. If data for collection development policy failure (i.e., the policy did not call for the book's acquisition), which Rashid used as a separate branch, is included, 800 of 949 attempts were successful for an 84.3 percent availability rate.

5. The availability rate is 68.3 percent if the 8 items received but not cataloged (which Boekhorst used as a separate branch) are considered. 607 ( 80.8 percent) were acquired by the library system, but not necessarily available in the main library.

6. Includes books, reserve items, and serial articles.

7. Data includes a built-in correction factor for the 4 cases where it was impossible to determine the cause of unavailability.

8. Based on the one day for which complete data was presented of a five-day study.

9. Calculated by the author from Salter's raw data.

10. Includes books and journal articles. The reason for unavailability could not be determined for 1 item in the 607 item sample.

11. This percentage calculated by the author from Chaudhry and Ashoor's raw data, who erroneously reported 88.1 percent as a result of applying Kantor's branches in reverse order.

12. The term "selection" was used for the acquisitions branch.

13. Calculated by the author from Jacobs' raw data.

14. Urs and Dominic reported 93 percent.

15. Journal articles.

16. Data includes a built-in correction factor for 50 failures due to bibliographic error, bad citations, or undetermined reasons. 


\section{Appendix D. Availability Rates in Kantor's Catalog Branch}

\section{Authors}

Wood, Bremer, and Saraidaridis

Kuraim

Abduljalil, Cleveland Heights

Abduljalil, Shaker Heights

Ajlan, King Saud U.

Ajlan, Petroleum and Minerals U.

Ferl and Robinson

Ciliberti et al.

Bachmann-Derthick and Spurlock ${ }^{3}$

Rashid

Boekhorst

Harris and Garner

Lieshout

Rehman and Bashir

Mitchell, Radford, and Hegg

Rehman, Arif, and Chaudhry

Jacobs, spring 1994 survey

Jacobs, fall 1994 survey

Ciliberti et al.

Ciliberti et al., journal articles

Shaw-Kokot and Varre ${ }^{10}$

\section{Pub. Year}

1980

1983

1985

1985

1985

1985

1986

1987

1989

1990

1992

1992

1992

1993

1994

1994

1995

1995

1998

1998

2001

\section{Number of Searches}

$$
287
$$

$$
486
$$$$
389
$$$$
393
$$$$
414
$$$$
450
$$

$$
368
$$$$
185
$$

411.8

$$
800
$$$$
513
$$$$
478^{6}
$$$$
293.5
$$$$
250.4
$$$$
55
$$$$
390
$$$$
3,921^{8}
$$$$
1,529^{9}
$$$$
171
$$$$
80
$$$$
1,941.3
$$

Successes

264.7

$454^{1}$

365

375

$377^{2}$

430

346

170

$355.6^{4}$

$775^{5}$

488

433

272.3

$249.4^{7}$

54

375

3,881

1,517

158

77

$1,911.4^{11}$
Percent

Available

92.2

93.4

93.8

95.4

91.1

95.6

94.0

91.9

86.4

96.9

95.1

90.6

92.8

99.6

98.2

96.2

99.0

99.2

92.4

96.3

98.5

\section{Notes}

1. There were 454 successes and a 93.4 percent success rate without librarian assistance increasing to 480 and a 98.8 percent success rate with librarian assistance.

2. Ajlan reported 374 , but analysis of the raw data and reported percentages indicates 377 is the correct number.

3. Journal articles.

4. Data includes a built-in correction factor for the 31 cases where it was impossible to determine the cause of unavailability.

5. There were 775 successes and a 96.9 percent success rate without librarian assistance increasing to 789 and a 98.6 percent success rate with librarian assistance.

6. Includes books, reserve items, and serial articles.

7. Data includes a built-in correction factor for the 4 cases where it was impossible to determine the cause of unavailability.

8. Calculated by the author from Jacobs' raw data.

9. Calculated by the author from Jacobs' raw data.

10. Journal articles.

11. Data includes a built-in correction factor for 50 failures due to bibliographic error, bad citations, or undetermined reasons. 


\section{Appendix E. Availability Rates in Kantor's Circulation Branch}

\section{Authors}

Abduljalil, Cleveland Heights

Abduljalil, Shaker Heights

Ajlan, King Saud U.

Ajlan, Petroleum and Minerals U.

Kolner and Welch, Illinois-Chicago

Kolner and Welch, Illinois-Peoria

Kolner and Welch, Illinois-Rockford

Ferl and Robinson

Ciliberti et al.

Revill

Revill

Bachmann-Derthick and Spurlock ${ }^{2}$

Roberts $^{4}$

Rashid

Boekhorst

Harris and Garner

Lieshout

Rehman and Bashir

Salter

Chaudhry and Ashoor

Mitchell, Radford, and Hegg

Rehman, Arif, and Chaudhry

Jacobs, spring 1994 survey

Jacobs, fall 1994 survey

Ciliberti et al

Ciliberti et al., journal articles

Urs and Dominic, Anna U.

Urs and Dominic, Bharathiar U.

Urs and Dominic, Bharathidasan U.

Urs and Dominic, Tamilnadu U.

Shaw-Kokot and Varre ${ }^{17}$

\section{Pub. Year}

1985

1985

1985

1985

1985

1985

1985

1986

1987

1987

1988

1989

1989

1990

1992

1992

1992

1993

1993

1994

1994

1994

1995

1995

1998

1998

1999

1999

1999

1999

2001

\section{Number of Searches}

365

375

377

430

711.5

56

55

346

170

$1,347.5$

Not Reported

355.6

202

$775^{5}$

488

$433^{7}$

272.3

249.4

$117^{9}$

$555^{11}$

54

375

$3,881^{13}$

$1,517^{14}$

158

77

$1,195^{15}$

660

751

1,078

$1,911.4$

\section{Successes}

346

359

$343^{1}$

336

596.5

44.33

47

284

155

1,187

Not Reported

$343.9^{3}$

197

$692^{6}$

323

342

229.8

$229^{8}$

102

493

53

309

3,260

1,341

139

77

1,049

550

616

962

$1894.2^{18}$
Percent

Available

94.8

95.7

91.0

78.1

83.8

79.2

85.5

82.1

91.2

88.1

91

96.7

97.5

89.3

66.2

79.0

84.4

91.8

$87.2^{10}$

$88.8^{12}$

98.1

82.4

84.0

88.4

88.0

100.0

$87.8^{16}$

83.3

82.0

89.2

99.1

\section{Notes}

1. Ajlan reported 340 successes in 374 searches, but analysis of the raw data and reported percentages indicates the correct figures are 343 successes in 377 searches.

2. Journal articles.

3. Data includes a built-in correction factor for the 31 cases where it was impossible to determine the cause of unavailability.

4. Journal articles.

5. 775 attempts without librarian assistance, 789 with librarian assistance.

6. There were 692 successes and a 89.3 percent success rate without librarian assistance increasing to 706 and a 89.5 percent success rate with librarian assistance.

7. Includes books, reserve items, and serial articles.

8. Data includes a built-in correction factor for the 4 cases where it was impossible to determine the cause of unavailability.

9. Based on the one day for which complete data was presented of a fiveday study.

10. Calculated by the author from Salter's raw data.

11. Includes books and journal articles. Number calculated by author from Chaudhry and Ashoor's raw data.

12. This percentage calculated by the author from Chaudhry and Ashoor's raw data, who erroneously reported 87.4 percent as a result of applying Kantor's branches in reverse order.

13. Calculated by the author from Jacobs' raw data. Jacobs also included items "on order" and declared missing in this branch.

14. Calculated by the author from Jacobs' raw data. Jacobs also included items "on order" and declared missing in this branch.

15. Corrected number calculated by author from raw data of Urs and Dominic

16. Urs and Dominic reported 87 percent.

17. Journal articles.

18. Data includes a built-in correction factor for 50 failures due to bibliographic error, bad citations, or undetermined reasons. 


\section{Appendix F. Availability Rates in Kantor's Library Operations Branch}

\begin{tabular}{|c|c|c|c|c|}
\hline Authors & $\begin{array}{l}\text { Pub. } \\
\text { Year }\end{array}$ & $\begin{array}{l}\text { Number of } \\
\text { Searches }\end{array}$ & Successes & $\begin{array}{c}\text { Percent } \\
\text { Available }\end{array}$ \\
\hline Abduljalil, Cleveland Heights & 1985 & 346 & 243 & 70.2 \\
\hline Abduljalil, Shaker Heights & 1985 & 359 & 268 & 74.7 \\
\hline Ajlan, King Saud U. & 1985 & $343^{1}$ & 315 & 91.8 \\
\hline Ajlan, Petroleum and Minerals U. & 1985 & 336 & 286 & 85.1 \\
\hline Kolner and Welch, Illinois-Chicago & 1985 & 596.5 & 491.5 & 82.4 \\
\hline Kolner and Welch, Illinois-Peoria & 1985 & 44.33 & 37 & 83.5 \\
\hline Kolner and Welch, Illinois-Rockford & 1985 & 47 & 46 & 97.9 \\
\hline Ferl and Robinson & 1986 & 284 & 259 & 91.2 \\
\hline Ciliberti et al. & 1987 & 155 & 115 & 74.2 \\
\hline Revill & 1987 & 1,187 & $1,122.5$ & 94.6 \\
\hline Revill & 1988 & Not Reported & Not Reported & 97 \\
\hline Bachmann-Derthick and Spurlock ${ }^{2}$ & 1989 & 343.9 & $297.1^{3}$ & 86.4 \\
\hline Roberts $^{4}$ & 1989 & 197 & 183 & 92.9 \\
\hline Rashid & 1990 & $692^{5}$ & $643^{6}$ & 92.9 \\
\hline Boekhorst & 1992 & 323 & 315 & 97.5 \\
\hline Harris and Garner & 1992 & $342^{7}$ & 283 & 82.7 \\
\hline Lieshout & 1992 & 229.8 & 227.3 & 98.9 \\
\hline Rehman and Bashir & 1993 & 229 & $150.5^{8}$ & 65.7 \\
\hline Salter & 1993 & $102^{9}$ & 92 & $90.2^{10}$ \\
\hline Chaudhry and Ashoor & 1994 & $493^{11}$ & 438 & $88.8^{12}$ \\
\hline Mitchell, Radford, Hegg & 1994 & 53 & 46 & 86.8 \\
\hline Rehman, Arif, and Chaudhry & 1994 & 309 & 300 & 97.1 \\
\hline Jacobs, spring 1994 survey & 1995 & $3,260^{13}$ & 2,939 & $90.2^{14}$ \\
\hline Jacobs, fall 1994 survey & 1995 & $1,341^{15}$ & 1,257 & $93.7^{16}$ \\
\hline Ciliberti et al. & 1998 & 139 & 127 & 91.4 \\
\hline Ciliberti et al., journal articles & 1998 & 67 & 57 & 85.1 \\
\hline Urs and Dominic, Anna U. & 1999 & 1,049 & 956 & 91.1 \\
\hline Urs and Dominic, Bharathiar U. & 1999 & 550 & 511 & 92.9 \\
\hline Urs and Dominic, Bharathidasan U. & 1999 & 616 & 594 & 96.4 \\
\hline Urs and Dominic, Tamilnadu U. & 1999 & 962 & 865 & $89.9^{17}$ \\
\hline Shaw-Kokot and Varre ${ }^{18}$ & 2001 & $1,894.2$ & $1,721.7^{19}$ & 90.9 \\
\hline
\end{tabular}

\section{Notes}

1. Ajlan reported 315 successes in 340 searches, but analysis of the raw data and reported percentages indicates the correct figures are 315 successes in 343 searches.

2. Journal articles.

3. Data includes a built-in correction factor for the 31 cases where it was impossible to determine the cause of unavailability.

4. Journal articles.

5. 692 attempts without librarian assistance, 706 with assistance.

6. There were 643 successes and a 92.9 percent success rate without librarian assistance increasing to 657 and a 93.1 percent success rate with librarian assistance.

7. Includes books, reserve items, and serial articles.

8. Data includes a built-in correction factor for the four cases where it was impossible to determine the cause of unavailability.

9. Based on the one day for which complete data was presented of a five-day study.

10. Calculated by the author from Salter's raw data.

11. Includes books and journal articles. Number calculated by author from Chaudhry and Ashoor's raw data.

12. This percentage calculated by the author from Chaudhry and Ashoor's raw data, who erroneously reported 89.9 percent as a result of applying Kantor's branches in reverse order.

13. Calculated by the author from Jacobs' raw data. Jacobs created separate branches for "mislaid," temporarily absent," and "slightly misfiled."

14. Calculated by the author from Jacobs' raw data.

15. Calculated by the author from Jacobs' raw data. Jacobs created separate branches for "mislaid," temporarily absent," and "slightly misfiled."

16. Calculated by the author from Jacobs' raw data.

17. Urs and Dominic reported 89 percent.

18. Journal articles.

19. Data includes a built-in correction factor for 50 failures due to bibliographic error, bad citations, or undetermined reasons. 


\section{Appendix G. Availability Rates in Kantor's User Branch as Defined and Reported by Original Investigators}

\begin{tabular}{|c|c|c|c|c|}
\hline Authors & Pub. Year & $\begin{array}{l}\text { Number of } \\
\text { Searches }\end{array}$ & Successes & $\begin{array}{c}\text { Percent } \\
\text { Available }\end{array}$ \\
\hline Wood, Bremer, and Saraidaridis & 1980 & 144.5 & 132 & 91.3 \\
\hline Kuraim & 1983 & $291^{1}$ & $262^{2}$ & 90.0 \\
\hline Abduljalil, Cleveland Heights & 1985 & 243 & 203 & 83.5 \\
\hline Abduljalil, Shaker Heights & 1985 & 268 & 236 & 88.1 \\
\hline Ajlan, King Saud U. & 1985 & 315 & 265 & 84.1 \\
\hline Ajlan, Petroleum and Minerals U. & 1985 & 286 & 268 & 93.7 \\
\hline Kolner and Welch, Illinois-Chicago & 1985 & 491.5 & 447 & 90.9 \\
\hline Kolner and Welch, Illinois-Peoria & 1985 & 37 & 35 & 94.6 \\
\hline Kolner and Welch, Illinois-Rockford & 1985 & 46 & 44 & 95.7 \\
\hline Ferl and Robinson & 1986 & 259 & 250 & 96.5 \\
\hline Ciliberti et al. & 1987 & 115 & 107 & 93.0 \\
\hline Revill & 1987 & $1,122.5$ & 1,003 & 89.4 \\
\hline Revill & 1988 & Not Reported & Not Reported & 92 \\
\hline Bachmann-Derthick and Spurlock ${ }^{3}$ & 1989 & 297.1 & $269^{4}$ & 90.5 \\
\hline Roberts $^{5}$ & 1989 & 183 & 162 & 88.5 \\
\hline Rashid & 1990 & $643^{6}$ & $596^{7}$ & 92.7 \\
\hline Boekhorst & 1992 & 315 & 254 & $80.6^{8}$ \\
\hline Harris and Garner & 1992 & $283^{9}$ & 259 & 91.5 \\
\hline Rehman and Bashir & 1993 & 150.5 & $124^{10}$ & 82.4 \\
\hline Salter & 1993 & $92^{11}$ & 86 & $93.5^{12}$ \\
\hline Chaudhry and Ashoor & 1994 & $438^{13}$ & 381 & $87.0^{14}$ \\
\hline Mitchell, Radford, and Hegg ${ }^{15}$ & 1994 & 46 & 40 & 87.0 \\
\hline Rehman, Arif, and Chaudhry & 1994 & 300 & 233 & 77.7 \\
\hline Jacobs, spring 1994 survey & 1995 & $2,939^{16}$ & 2,566 & 87.3 \\
\hline Jacobs, fall 1994 survey & 1995 & $1,257^{17}$ & 1,136 & 90.4 \\
\hline Ciliberti et al. ${ }^{18}$ & 1998 & 127 & 119 & 93.7 \\
\hline Ciliberti et al., journal articles ${ }^{19}$ & 1998 & 77 & 68 & 88.3 \\
\hline Urs and Dominic, Anna U. & 1999 & 956 & 855 & 89.4 \\
\hline Urs and Dominic, Bharathiar U. & 1999 & 511 & 460 & 90.0 \\
\hline Urs and Dominic, Bharathidasan U. & 1999 & 594 & 544 & $91.6^{20}$ \\
\hline Urs and Dominic 1999, Tamilnadu U. & 1999 & 865 & 766 & $88.6^{21}$ \\
\hline Shaw-Kokot and Varre ${ }^{22}$ & 2001 & $1,721.7$ & $1,663^{23}$ & 96.6 \\
\hline
\end{tabular}

\section{Notes}

1. 291 without librarian assistance, 311 with assistance.

2. There were 262 successes and a 90.0 percent success rate without librarian assistance increasing to 304 and a 97.7 percent success rate with librarian assistance.

3. Journal articles.

4. Data includes a built-in correction factor for the 31 cases where it was impossible to determine the cause of unavailability.

5. Journal articles.

6. 643 attempts without librarian assistance; 657 with assistance.

7. There were 596 successes and a 92.7 percent success rate without librarian assistance increasing to 657 and a 96.7 percent success rate with librarian assistance.

8. Calculated by author from the original researcher's raw data, who reported 86.2 percent.

9. Includes books, reserve items, and serial articles.

10. Data includes a built-in correction factor for the four cases where it was impossible to determine the cause of unavailability.
11. Based on the one day for which complete data was presented of a five-day study.

12. Calculated by the author from Salter's raw data.

13. Includes books and journal articles. Number calculated by author from Chaudhry and Ashoor's raw data.

14. This percentage calculated by the author from Chaudhry and Ashoor's raw data, who erroneously reported 90.6 percent as a result of applying Kantor's branches in reverse order.

15. The term "retrieval" was used for the user at the shelf branch.

16. Calculated by the author from Jacobs' raw data.

17. Calculated by the author from Jacobs' raw data.

18. Used term "retrieval" for this branch.

19. Used term "patron retrieval" for this branch.

20. Urs and Dominic reported 91 percent.

21. Urs and Dominic reported 88 percent.

22. Journal articles.

23. Data includes a built-in correction factor for 50 failures due to bibliographic error, bad citations, or undetermined reasons. 


\section{Appendix H. Analysis of Failures in Kantor's Branches (All User Failures Combined)}

(The percentage of total failures in the study attributed to each branch is indicated in parentheses)

Authors
Wood, Bremer, and Saraidaridis
Kuraim
Tamura and Sakai
Abduljalil, Cleveland Heights
Abduljalil, Shaker Heights
Ajlan, King Saud U.
Ajlan, Petroleum and Minerals U.
Kolner and Welch, Illinois-Chicago
Kolner and Welch, Illinois-Peoria
Kolner and Welch, Illinois-Rockford
Ferl and Robinson
Ciliberti et al.
Revill
Bachmann-Derthick and Spurlock
Roberts
Rashid
Boekhorst
Harris and Garner
Lieshout
Rehman and Bashir
Salter
Chaudhry and Ashoor
Mitchell, Radford, and Hegg
Rehman, Arif, and Chaudhry
Jacobs, spring 1994 survey
Jacobs, fall 1994 survey
Ciliberti et al.
Ciliberti et al., Journal articles
Urs and Dominic, Anna U.
Urs and Dominic, Bharathiar U.
Urs and Dominic, Bharathidasan U.
Urs and Dominic, Tamilnadu U.
Shaw-Kokot and Varre
Total Number
Total Percentage
The

Notes

1. Circulation and library operations were combined into a single branch accounting for 120.2 failures, 55.1 percent of total.

2. Circulation and library operations were combined into a single branch accounting for 163 failures, 68.5 percent of total.

3. Circulation, library operations, and the user were combined into a single branch accounting for 9 failures, 64.3 percent of the total.

4. This row adds to 214.2 due to the correction factor used by BachmannDerthick and Spurlock, but the actual number of failed searches was 214.

5. Total for collection development and acquisitions branches combined.

6. Includes titles received but not cataloged, which Boekhorst used as a separate branch.

7. This row adds to 175.4 due to the correction factor used by Rehman and Bashir, but the actual number of failed searches was 176 .

\begin{tabular}{|c|c|c|c|}
\hline Circulation & Library & User & Total \\
\hline 1 & & $34.8(16.0 \%)$ & 218 \\
\hline 2 & & $61(25.6 \%)$ & 238 \\
\hline & & & 14 \\
\hline $19(8.3 \%)$ & $103(45.0 \%)$ & $64(27.9 \%)$ & 229 \\
\hline $16(8.2 \%)$ & $91(46.4 \%)$ & $50(25.5 \%)$ & 196 \\
\hline $34(14.5 \%)$ & $28(11.9 \%)$ & $96(40.9 \%)$ & 235 \\
\hline $94(40.5 \%)$ & $50(21.6 \%)$ & $62(26.7 \%)$ & 232 \\
\hline $115(36.7 \%)$ & $105(33.5 \%)$ & $44.5(14.2 \%)$ & 313 \\
\hline $11.67(38.9 \%)$ & $7.33(24.4 \%)$ & $2(6.7 \%)$ & 30 \\
\hline $8(50.0 \%)$ & $1(6.25 \%)$ & $2(12.5 \%)$ & 16 \\
\hline $62(39.2 \%)$ & $25(15.8 \%)$ & $31(19.6 \%)$ & 158 \\
\hline $15(14.4 \%)$ & $40(38.5 \%)$ & $28(26.9 \%)$ & 104 \\
\hline $160.5(35.3 \%)$ & $64.5(14.2 \%)$ & $119.5(26.3 \%)$ & 455 \\
\hline $11.7(5.5 \%)$ & $46.8(21.9 \%)$ & $84.3(39.4 \%)$ & $214^{4}$ \\
\hline $5(3.7 \%)$ & $14(10.4 \%)$ & $21(15.6 \%)$ & 135 \\
\hline $83(20.5 \%)$ & $49(12.1 \%)$ & $123(30.4 \%)$ & 404 \\
\hline $165(33.2 \%)$ & $8(1.6 \%)$ & $86(17.3 \%)$ & 497 \\
\hline $91(27.6 \%)$ & $59(17.9 \%)$ & $69(20.9 \%)$ & 330 \\
\hline $42.5(24.5 \%)$ & $2.5(1.4 \%)$ & $21.2(12.2 \%)$ & 173.7 \\
\hline $20.4(11.6 \%)$ & $78.5(44.6 \%)$ & $27.5(15.6 \%)$ & $176^{7}$ \\
\hline $15(39.5 \%)$ & $10(26.3 \%)$ & $6(15.8 \%)$ & 38 \\
\hline $62(27.4 \%)$ & $55(24.3 \%)$ & $57(25.2 \%)$ & $226^{8}$ \\
\hline $1(4.8 \%)$ & $7(33.3 \%)$ & $9(42.9 \%)$ & 21 \\
\hline $66(31.7 \%)$ & $9(4.3 \%)$ & $82(39.4 \%)$ & 208 \\
\hline $621(40.4 \%)$ & $321(20.9 \%)$ & $478(31.1 \%)$ & 1,537 \\
\hline $176(39.2 \%)$ & $84(18.7 \%)$ & $133(29.6 \%)$ & 449 \\
\hline $19(25.0 \%)$ & $12(15.8 \%)$ & $25(32.9 \%)$ & 76 \\
\hline $0(0 \%)$ & $10(14.3 \%)$ & $16(22.9 \%)$ & $70^{10}$ \\
\hline $146(36.6 \%)$ & $93(23.3 \%)$ & $101(25.3 \%)$ & 399 \\
\hline $110(26.8 \%)$ & $39(9.5 \%)$ & $51(12.4 \%)$ & 410 \\
\hline $135(32.7 \%)$ & $22(5.3 \%)$ & $50(12.1 \%)$ & 413 \\
\hline $116(30.2 \%)$ & $97(25.3 \%)$ & $99(25.8 \%)$ & 384 \\
\hline $17.2(4.4 \%)$ & $172.5(43.9 \%)$ & $88.6(22.5 \%)$ & $393^{11}$ \\
\hline $2,437.97$ & $1,704.13$ & $2,222.4$ & $8991.7^{1}$ \\
\hline $1 \%$ & $19.0 \%$ & $24.7 \%$ & \\
\hline
\end{tabular}

8. This row adds to 225 because the cause of 1 unsuccessful search could not be determined, but the actual number of failed searches was 226.

9. The bibliographic and acquisitions branches were combined, accounting for 56 failures, 12.5 percent of the total.

10. The row adds to 69 because 1 failure at a "library retrieval" branch is included in this total.

11. This row adds to 394.3 due to the correction factor used by ShawKokot and Varre, but the actual number of failed searches was 393.

12. There were $8,991.7$ failures, including 350.2 (3.9 percent of total failures) that could not be directly attributed to one of the four main branches (usually due to combining branches). 


\section{Appendix I. Availability Rates in Simulated Studies Not Involving Actual Patrons}

\begin{tabular}{|c|c|c|c|c|c|}
\hline Authors & Pub. Yr & Library & $\begin{array}{l}\text { Number of } \\
\text { Searches }\end{array}$ & Successes & $\begin{array}{l}\text { Percent } \\
\text { Available }\end{array}$ \\
\hline Kuraim & 1983 & $\begin{array}{l}\text { Cleveland Heights- } \\
\text { University Heights Main } \\
\text { Public Library }\end{array}$ & $500^{1}$ & 65 & 13.0 \\
\hline Kuraim & 1983 & $\begin{array}{l}\text { Cleveland Heights- } \\
\text { University Heights Main } \\
\text { Public Library }\end{array}$ & $500^{2}$ & 321 & 64.2 \\
\hline Stelk and Lancaster & 1990 & $\begin{array}{l}\text { University of Illinois, } \\
\text { Undergrad. Library }\end{array}$ & $450^{3}$ & 360 & 80.0 \\
\hline Stelk and Lancaster & 1990 & $\begin{array}{l}\text { University of Illinois, } \\
\text { Undergrad. Library }\end{array}$ & $450^{4}$ & 316 & 70.2 \\
\hline Steynberg and Rossouw & 1993 & $\begin{array}{l}\text { University of Cape Town, } \\
\text { South Africa }\end{array}$ & $307^{5}$ & 213 & 69.4 \\
\hline Chaudhry and Ashoor & 1994 & $\begin{array}{l}\text { King Fahd University of } \\
\text { Petroleum and Minerals, } \\
\text { Saudi Arabia }\end{array}$ & $300^{6}$ & 138 & 46.0 \\
\hline Chaudhry and Ashoor & 1994 & $\begin{array}{l}\text { King Fahd University of } \\
\text { Petroleum and Minerals, } \\
\text { Saudi Arabia }\end{array}$ & $300^{7}$ & 252 & 84.0 \\
\hline Chandler & 1998 & $\begin{array}{l}\text { Cameron Village Regional } \\
\text { Library }^{8}\end{array}$ & $508^{9}$ & 345 & 67.9 \\
\hline
\end{tabular}

\section{Notes}

1. Sample from the last five volumes of the American Book Publishing Record.

2. A shelf list sample.

3. A shelf list sample.

4. A sample of items previously charged out.

5. Citations to journal articles published by South African biomedical researchers.
6. 200 books from Scientific and Technical Books and 100 serials from Magazines for Libraries.

7. A shelf list sample.

8. In the Wake County Public Library system in North Carolina.

9. A sample of recently circulating materials. 